\title{
The implementation of NEMS GFS Aerosol Component (NGAC) Version 1.0 for global dust forecasting at NOAA/NCEP
}

\author{
Cheng-Hsuan Lu ${ }^{1,2}$, Arlindo da Silva ${ }^{3}$, Jun Wang ${ }^{2}$, Shrinivas Moorthi ${ }^{4}$, Mian Chin ${ }^{3}$, Peter Colarco ${ }^{3}$, Youhua Tang ${ }^{5}$, \\ Partha S. Bhattacharjee ${ }^{2}$, Shen-Po Chen ${ }^{1}$, Hui-Ya Chuang ${ }^{4}$, Hann-Ming Henry Juang ${ }^{4}$, Jeffery McQueen ${ }^{4}$, and \\ Mark Iredell ${ }^{4}$ \\ ${ }^{1}$ University at Albany, State University of New York, Albany, NY, USA \\ ${ }^{2}$ I. M. Systems Group, Inc. at NOAA/NWS National Centers for Environmental Prediction, College Park, MD, USA \\ ${ }^{3}$ NASA Goddard Space Flight Center, Greenbelt, MD, USA \\ ${ }^{4}$ NOAA/NWS National Centers for Environmental Prediction, College Park, MD, USA \\ ${ }^{5}$ NOAA/OAR Air Resources Laboratory, College Park, MD, USA \\ Correspondence to: Cheng-Hsuan Lu (sarah.lu@ noaa.gov, clu4@albany.edu)
}

Received: 23 October 2015 - Published in Geosci. Model Dev. Discuss.: 15 January 2016

Revised: 27 April 2016 - Accepted: 27 April 2016 - Published: 20 May 2016

\begin{abstract}
The NOAA National Centers for Environmental Prediction (NCEP) implemented the NOAA Environmental Modeling System (NEMS) Global Forecast System (GFS) Aerosol Component (NGAC) for global dust forecasting in collaboration with NASA Goddard Space Flight Center (GSFC). NGAC Version 1.0 has been providing 5-day dust forecasts at $1^{\circ} \times 1^{\circ}$ resolution on a global scale, once per day at 00:00 Coordinated Universal Time (UTC), since September 2012. This is the first global system capable of interactive atmosphere aerosol forecasting at NCEP. The implementation of NGAC V1.0 reflects an effective and efficient transitioning of NASA research advances to NCEP operations, paving the way for NCEP to provide global aerosol products serving a wide range of stakeholders, as well as to allow the effects of aerosols on weather forecasts and climate prediction to be considered.
\end{abstract}

\section{Introduction}

Aerosols affect the energy balance of Earth's atmosphere through the absorption and scattering of solar and thermal radiation (Mitchell Jr., 1971). Aerosols also affect Earth's climate through their effects on cloud microphysics, reflectance, and precipitation (Twomey, 1974; Albrecht, 1989; Jones et al., 1994; Lohmann et al., 2000). In addition to modulating Earth's climate and hydrological cycle (Ramanathan et al., 2001), aerosols are important for atmospheric chemistry, the biosphere, and public health. Aerosols can be viewed in their role as air pollutants because of their adverse health effects (Pöschl, 2005). Long-range transport of aerosols can affect the air quality and visibility far from the source regions (Prospero, 1999; Jaffe et al., 2003; Colarco et al., 2004). In addition, aerosols may play a significant role in atmospheric oxidation processes (Andreae and Crutzen, 1997; Dickerson et al., 1997). Large amounts of mineral dust are deposited to the oceans (Duce, 1991; Prospero et al., 1996) and the atmospheric input is found to be important for marine productivity (Chen et al., 2007).

While the importance of aerosols on climate has long been established, it is only recently that the aerosol effects are being increasingly recognized as important for weather predictions (Pérez et al., 2006; Mulcahy et al., 2014). Haywood et al. (2005) shows that the neglect of the radiative effects of mineral dust leads to systematic biases in the top-of-theatmosphere radiative budget in the UK Met Office (UKMO) numerical weather prediction (NWP) model. By prescribing updated aerosol climatology in the European Centre for Medium-Range Weather Forecasts (ECMWF) NWP model, a shift in the African Easterly Jet (AEJ) in better agreement with observations is demonstrated in Tompkins et al. (2005) and improvements in local medium-range forecast skills and global seasonal mean are shown in Rodwell and Jung (2008). A number of studies have suggested that aerosols can signif- 
icantly impact severe weather, such as intensifying Pacific storm track (Zhang et al., 2007; Wang et al., 2014), modifying hurricane and tropical cyclones (Rosenfeld et al., 2012; Herbener et al., 2014), affecting deep convective storms and tornado intensity in the US (Wang et al., 2009; Saide et al., 2015), and enhancing catastrophic floods in southwest China (Fan et al., 2015).

Despite recent progress in atmospheric aerosol modeling, the physical processes crucial for modeling aerosol effects are either poorly represented or outright missing in National Centers for Environmental Prediction (NCEP) global models. The NCEP's Global Forecast System (GFS) is the cornerstone of NCEP's operational production suite of numerical guidance. The atmospheric forecast model used in the GFS is global spectrum model (GSM) with a comprehensive physics suite (see the GFS webpage at http://www.emc.ncep. noaa.gov/GFS/doc.php). Until now, the model only considers aerosol radiative effects and the aerosol distributions are prescribed based on a global climatological aerosol database (Hess et al., 1998).

Efforts to develop prognostic aerosol capability in NCEP global models have been underway in the last few years, which in turn are part of NCEP's modeling development efforts toward a unified modeling framework. Specifically, NCEP is developing NOAA Environmental Modeling System (NEMS) as its next-generation operational system (Black et al., 2007, 2009) and has collaborated with NASA/Goddard Space Flight Center (GSFC) to develop NEMS GFS Aerosol Component (NGAC) for predicting the distribution of atmospheric aerosols (Lu et al., 2010, 2013). NGAC is the first on-line (interactive) atmospheric aerosol forecast system at NCEP. It consists of two key modeling components: (1) the GFS within the NEMS architecture (NEMS GFS) and (2) the on-line aerosol module based on Goddard Chemistry Aerosol Radiation and Transport (GOCART) model. The advantages for taking the so-called online approach include: (1) consistency: no spatial-temporal interpolation and the use of the same physics parameterization, (2) efficiency: lower overall CPU costs and easier data management, and (3) interaction: allows for aerosol feedback to meteorology.

NGAC Version 1.0 (NGAC V1.0) has been implemented and became operational at NCEP since September 2012. It provides real-time short-range (5-day) forecasts of dust aerosols with global coverage. The development of a global aerosol forecast system in turn provides a first step toward an aerosol data assimilation capability at NCEP. The rationale for developing the global aerosol forecasting and data assimilation capabilities at NCEP includes (1) improving weather forecasts and climate predictions by taking into account of aerosol effects on radiation and clouds, (2) improving the handling of satellite observations by properly accounting for aerosol effects during the assimilation procedure; (3) providing aerosol (lateral and upper) boundary conditions for regional air quality predictions; and (4) providing global aerosol products to meet the stakeholder needs such as air quality, UV index, visibility, ocean productivity, solar energy production, and sea surface temperature (SST) retrievals.

Aerosol modeling, traditionally serving regional air quality and climate communities, has seen rapid development at several operational and research NWP centers in the last few years (Reid et al., 2011; Benedetti et al., 2011, 2014). This includes NCEP (discussed in this paper), ECMWF (Benedetti et al., 2009; Morcrette et al., 2009), UKMO (Woodward, 2001, 2011), Naval Research Laboratory (NRL, Zhang et al., 2008; Westphal et al., 2009), NASA Global Modeling and Assimilation Office (GMAO, Colarco et al., 2010), Japan Meteorological Agency (JMA, Tanaka et al., 2003), and Barcelona Supercomputing Centre (BSC, Pérez et al., 2011; Basart et al., 2012). In addition, the efforts to develop regional and global multi-model ensembles for aerosol prediction are underway (Sessions et al., 2015), offering aerosol products for research applications and eventually operational use. The implementation of NGAC V1.0 at NCEP not only contributes to the NCEP production suite but also to the international efforts for multi-model ensembles.

In this paper, we describe the development and implementation of NGAC V1.0 at NCEP. In Sect. 2, we describe the model configuration. In Sect. 3, we present the operational implementation of NGAC V1.0. In Sect. 4, we present the results of NGAC V1.0 forecasts and the comparisons to other global aerosol models and observations. In Sect. 5, we demonstrate two examples of NGAC V1.0 applications. Section 6 provides concluding remarks.

\section{Model configuration}

\subsection{Atmospheric model: NEMS GFS}

The efforts to develop a unified modeling framework to streamline the interaction of forecast, analysis, and postprocessing systems within NCEP have been underway since late 2000 (Black et al., 2007, 2009). Specifically, NCEP is developing NEMS (http://www.emc.ncep.noaa.gov/index. php?branch=NEMS) with a component-based architecture following the Earth System Modeling Framework (ESMF, see http://www.earthsystemmodeling.org). The ESMF is a community effort to promote the exchange and reusability of earth system modeling components and to facilitate faster knowledge transfer and technology adaptation. The ESMF collaboration involves many of the major climate, weather and data assimilation efforts in the United States, including NOAA/NCEP, NASA/GMAO, NRL, NOAA Geophysical Fluid Dynamics Laboratory (GFDL), and the National Center for Atmospheric Research (NCAR).

The development of NEMS aims to develop a common superstructure for NCEP production suite. Other motivations are (1) to reduce overhead costs and provide a flexible infrastructure in the operational environment, (2) to modular- 
ize large pieces of the systems with ESMF components and interfaces, and (3) to enable NOAA contribution to the National Unified Operational Prediction Capability (NUOPC) with Navy and Air Force.

The NEMS is organized into collections of components with standardized interfaces, arranged in a hierarchical structure. Currently the GFS, the B-grid version of the Nonhydrostatic Multiscale Model (NMM-B), and the Flow-following finite-volume Icosahedral Model (FIM) have been placed under the NEMS atmosphere framework. A unified parallelized I/O package is developed to handle the synchronous production and writing of history files, which in turn has been linked with NCEP's unified post-processing system. The FIM atmosphere model is developed by NOAA Earth System Research Laboratory (ESRL) for global weather prediction research. The NMM-B model, developed by NCEP, is the forecast model for the North American Mesoscale Forecast System (NAM) providing operational mesoscale weather forecasts since October 2011. The NEMS version of GFS (referred to as NEMS GFS in this paper) consists of the same spectral dynamic core and physics parameterizations as the operational GFS with the following exceptions. First, GFS atmospheric model has been restructured to include separate components for the model's dynamics and physics as well as a coupler through which information is passed between the dynamics and physics. Despite extensive use of ESMF superstructure, infrastructure and utilities in NEMS, the underlying science code, however, remains the same as the operational GFS. Second, enhanced I/O and post-processing capabilities are introduced in the NEMS GFS. These include an option to output history files in native Gaussian grids instead of spectral grids and an option to run model integration in parallel to post-processing. Third, GFS physics parameterizations have been re-structured with a flexible interface, allowing it to be called by other dynamic cores. This option to assemble GFS physics as the NEMS unified physics package again reflects NCEP's modeling strategy toward a unified and yet flexible modeling infrastructure.

The NEMS has been under active development. Efforts to incorporate non-atmospheric components, e.g., ocean, wave, and sea ice models, are underway. The coupling infrastructure is based on the ESMF and NUOPC Layer code and conventions. Development is also made to enable emerging environmental prediction capabilities. The aerosol forecasting capability, NGAC, discussed in this paper is virtually NEMS GFS with the prognostic aerosol option turned on.

\subsection{Aerosol model: GOCART}

Funded mainly by NASA Earth Science programs, the GOCART model was developed to simulate atmospheric aerosols (including sulfate, black carbon (BC), organic carbon (OC), dust, and sea salt) and sulfur gases (Chin et al., 2000, 2002, 2003, 2004, 2007, 2009; Ginoux et al., 2001, 2004; Bian et al., 2010; Colarco et al., 2010; Kim et al., 2013). Originally GOCART was developed as an offline constituent transport model (CTM), driven by assimilated meteorological fields from the Goddard Earth Observing System Data Assimilation System (GEOS DAS, e.g., Chin et al., 2002). As part of the GEOS Version 4 (GEOS4) atmospheric model development at NASA GMAO, an ESMF compliant GOCART grid component has been developed (Colarco et al., 2010). When running within versions 4 and 5 of GEOS (GEOS-4/5), the GOCART component provides aerosol processes such as emissions, sedimentation, dry and wet deposition (Fig. 1). Dynamic sources (windspeed dependent) are considered for dimethyl sulfide (DMS), dust, and sea salt. Emissions for $\mathrm{SO}_{2}$ and carbonaceous aerosols arise from nature and anthropogenic sources, including biogenic, biofuel, anthropogenic, and biomass burning emissions. Aerosol chemistry currently uses prescribed $\mathrm{OH}$, $\mathrm{H}_{2} \mathrm{O}_{2}$, and $\mathrm{NO}_{3}$ fields for DMS and $\mathrm{SO}_{2}$ oxidations. Aerosol sinks include wet removal (scavenging and rainout) and dry deposition (gravitational sedimentation and surface uptake). Advection, turbulent and convective transport is outside the scope of the GOCART component, being instead provided by the host atmospheric model. Unlike off-line CTM, this on-line aerosol module accurately utilizes winds, convective mass flux, and eddy diffusivity valid at each time step, without the need for temporal or spatial interpolation of any kind.

Research and development efforts have further enhanced GOCART modeling capabilities. The transition from offline to on-line coupling approach mentioned above is an example. In addition, the GOCART grid component now has the option to ingest daily biomass burning emissions from the Quick Fire Emission Dataset (QFED, Darmenov and da Silva, 2015). QFED emissions are based on fire radiative power retrievals from MODIS (Moderate Resolution Imaging Spectroradiometer, on board Aqua and Terra satellites). The inclusion of such observation-based, time-dependent emissions is important for the model to capture the large temporal-spatial variation of biomass burning emissions.

For dust, a topographic source function and mobilization scheme following Ginoux et al. (2001) is used. The dust emission parameterization depends on $10 \mathrm{~m}$ wind, the threshold velocity of wind erosion, and dust source function. The threshold velocity of wind erosion is determined from dust density, particle diameter, and surface soil wetness. The dust source function, representing the probability of dust uplifting, is determined from surface bareness and topographical depression features. Surface bareness is identified from the $1^{\circ} \times 1^{\circ}$ vegetation data set derived from the Advanced Very High Resolution Radiometer (AVHRR) data (DeFries and Townshend, 1994). The static dust source function has been regridded on the GFS native T126 Gaussian grid for NGAC V1.0 (shown in Fig. 2). The maxima of dust source function are collocated with the climatologically active dust sources or so-called dust hot spots. The most evident examples are the Sahara desert in northern Africa, the Bodele depression over Chad, the Syrian desert in the Middle East, the 


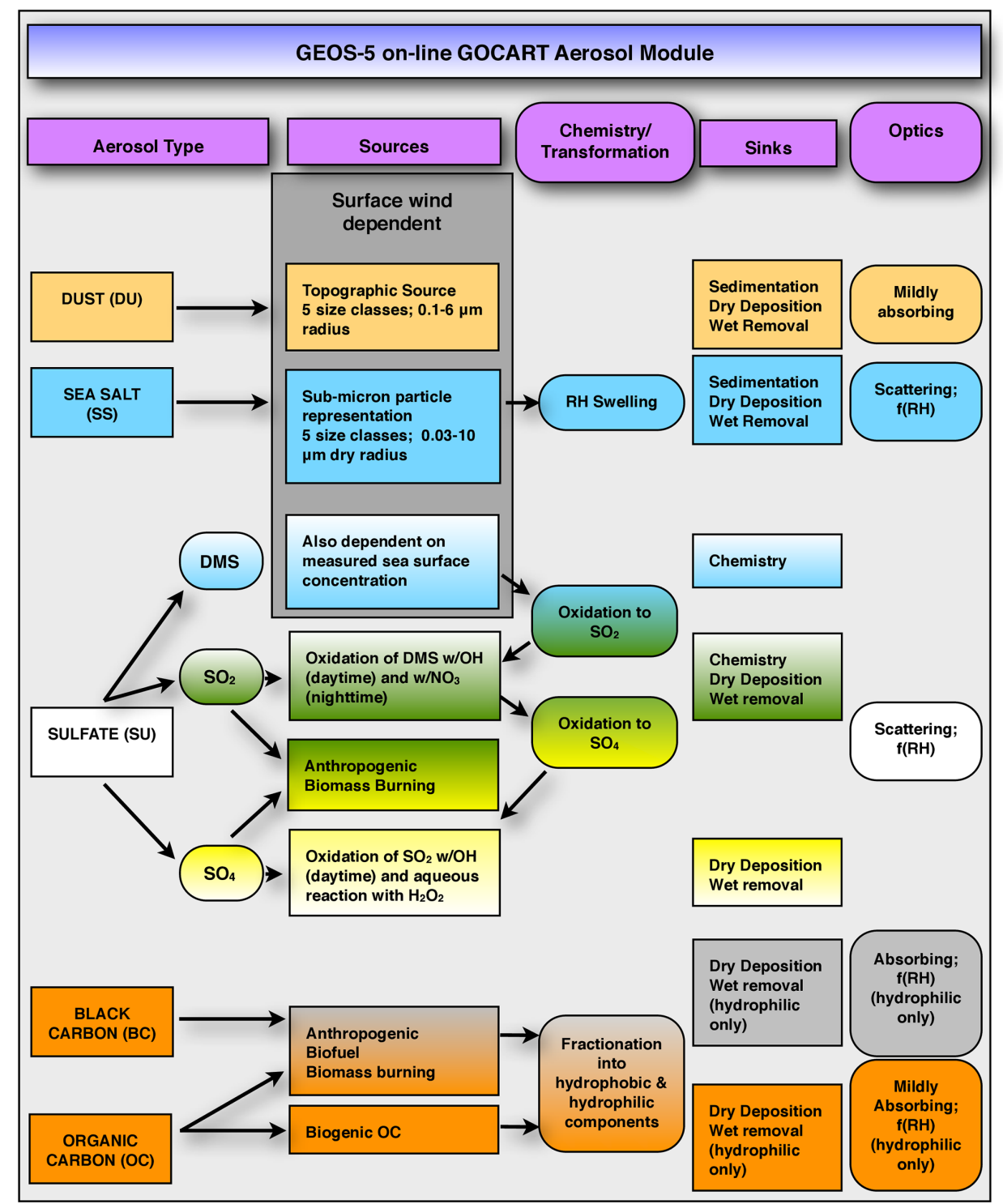

Figure 1. Schematic summary of the GOCART aerosol module as adapted and being implemented in GEOS-4/5 at GMAO and NEMS GFS at NCEP.

Taklamakan desert in northwest China, the Lake Eyre basin in Australia, the Sonoran desert in southwest California, the Namibian sources in southwest Africa, and Patagonian desert and Andean Plateau in the Andes.

\subsection{Coupling NEMS GFS with GOCART}

The GOCART grid component originally developed for GEOS-4/5 is fairly independent of the host atmospheric model, encapsulating the basic aerosol production and loss functionality. Consistent with standard ESMF architecture, the interfaces linking GOCART and NEMS GFS have been isolated into coupler components. Figure 3 shows the integration run stream of NGAC. Coupler components are built to transfer and transform the data between NEMS GFS and
GOCART. The physics-to-chemistry coupler performs several tasks including (i) the vertical flip for three-dimensional fields, as GOCART uses top-down while NEMS GFS uses bottom-up processing, (ii) unit conversion as different units are used in NEMS GFS and GOCART for some fields such as precipitation rate, and (iii) the calculations for these fields needed by GOCART such as inferring relative humidity and air density from ambient temperature and moisture fields. After running GOCART, the chemistry-to-physics coupler transfers updated three-dimensional aerosol fields and two-dimensional aerosol diagnosis fields from GOCART to NEMS GFS.

GOCART in GEOS- $4 / 5$ has been implemented in NEMS GFS "as is" except for emission budget. As in GEOS-4/5 


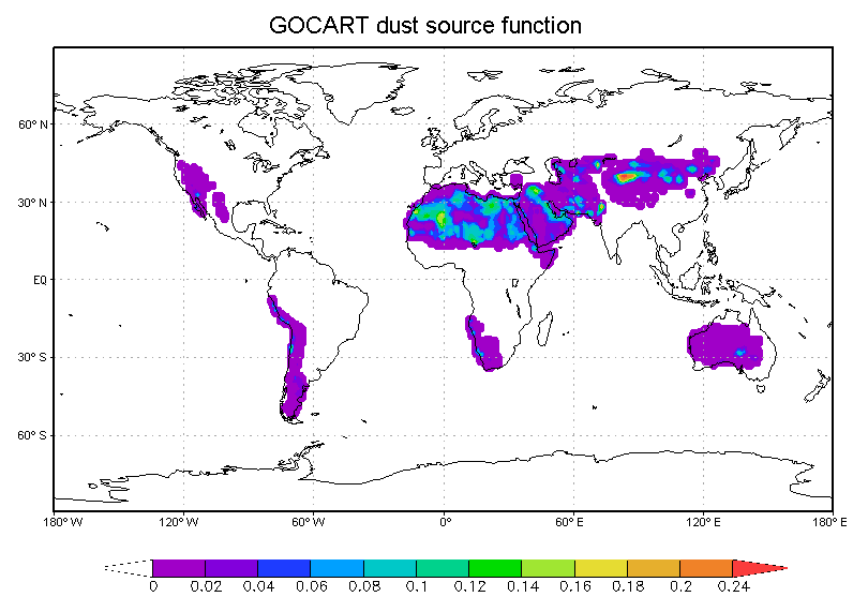

Figure 2. The dust source function or probability of dust uplifting, mapped to GFS T126 resolution, used in NGAC V1.0.

(Colarco et al., 2010), the spatial distribution and intensity of dust sources in NGAC V1 follows from Ginoux et al. (2001). Owing to differences in the GEOS-4/5 meteorology and resolution relative to NEMS GFS, the global scaling constant for dust emissions (see Eq. 2 in Ginoux et al., 2001) has been adjusted from $C=0.375 \mu \mathrm{g} \mathrm{s}^{2} \mathrm{~m}^{-5}$ as in GEOS-4/5 to $C=1 \mu \mathrm{g} \mathrm{s}^{2} \mathrm{~m}^{-5}$ in NGAC. This adjustment is determined from sensitivity experiments, allowing NGAC V1 to obtain dust emission budget comparable to GEOS-4/5.

Despite the ESMF flavor in how GOCART is implemented, GOCART is incorporated into NEMS GFS as a column process similar to how ozone physics was incorporated. It updates three-dimensional aerosol loading after physical processes, ran at the same grid as physics and dynamics, and is fully coupled with physics and dynamics at each time step.

\section{NGAC V1.0 operational implementation}

A phased approach is used to manage the operational implementation of NGAC at NCEP. The first phase is to produce dust-only guidance, the second phase is to produce the full suite of aerosol forecasts (including dust, sea salt, sulfate, and carbonaceous aerosols), and the third phase is to produce aerosol analysis using NGAC forecasts as first guess. Only the initial deployment undertaken in 2012 is discussed in this paper.

Effective on 11 September 2012, starting with the 00:00 UTC cycle, NCEP has begun to run and disseminate data from the NGAC V1.0 system at T126 L64 resolution. It provides 5-day dust forecasts, once per day for the 00:00 UTC cycle. Information on accessing NGAC model output is provided in the Appendix A. Daily web-based presentation of NGAC V1.0 dust forecasts is available at the EMC NGAC webpage: http://www.emc.ncep.noaa.gov/ $\mathrm{gmb} / \mathrm{NGAC} / \mathrm{html} /$ realtime.ngac.html. The website displays

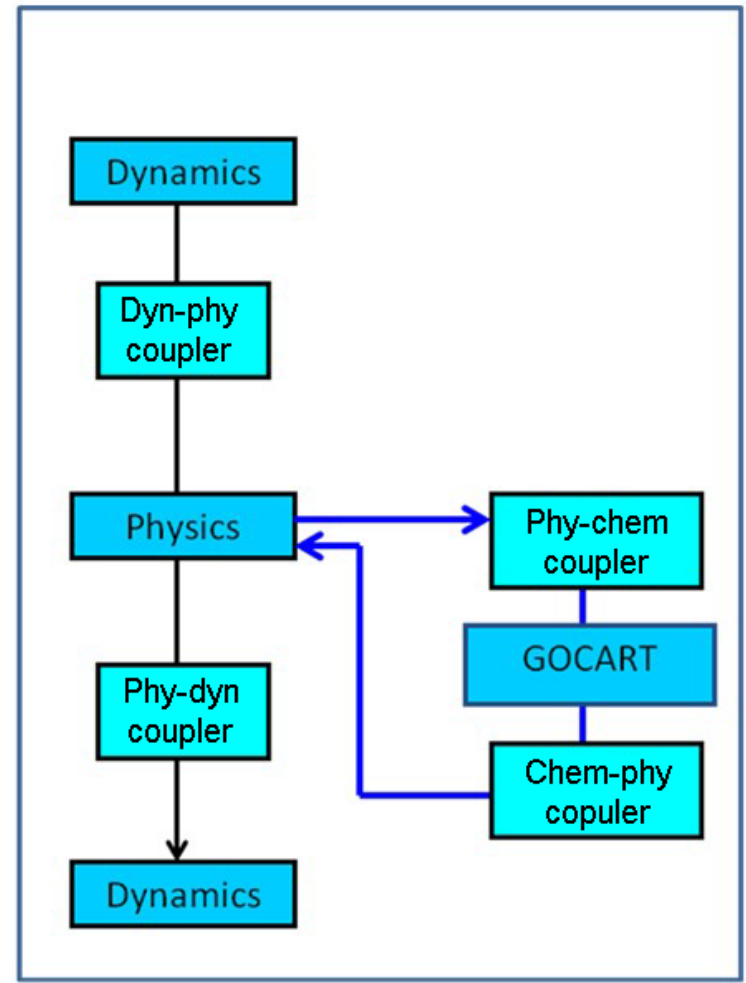

Figure 3. Primary integration runstream of NGAC.

aerosol optical depth (AOD) at $550 \mathrm{~nm}$ and surface mass concentrations over global domain and several regional domains (e.g., trans-Atlantic region, Asia, and continental US (CONUS) regions).

Model configurations in NGAC V1.0 are same as those specified in operational high-resolution GFS runs with the following exceptions. First, NGAC uses relaxed ArakawaSchubert scheme (the RAS scheme, Moorthi and Suarez, 1992, 1999) while GFS uses simplified Arakawa-Schubert scheme (the SAS scheme, Han and Pan, 2011). Enhanced tracer treatment (e.g., convective transport and tracer scavenging) has been incorporated into the RAS scheme, providing critical capability needed for aerosol modeling. Second, NGAC V1.0 is run at coarser spatial resolution (T126 L64, $\sim 110 \mathrm{~km})$ than GFS. In February 2015, GFS was upgraded from Eulerian T574 $(\sim 27 \mathrm{~km})$ to semi-Lagrangian T1534 $(\sim 13 \mathrm{~km})$. NGAC V1.0, however, remains Eulerian T126 as of October 2015. Third, NGAC V1.0 produces history files and post-processed products concurrently while GFS produces post-processed products after history files have been written out.

Dust initial conditions are taken from the $24 \mathrm{~h}$ NGAC V1.0 forecast from previous day while meteorological initial conditions are downscaled from high-resolution Global Data Assimilation System (GDAS) analysis. Note the interaction of GOCART aerosol fields and GFS's radiation package has been disabled in NGAC V1.0. This configuration that 


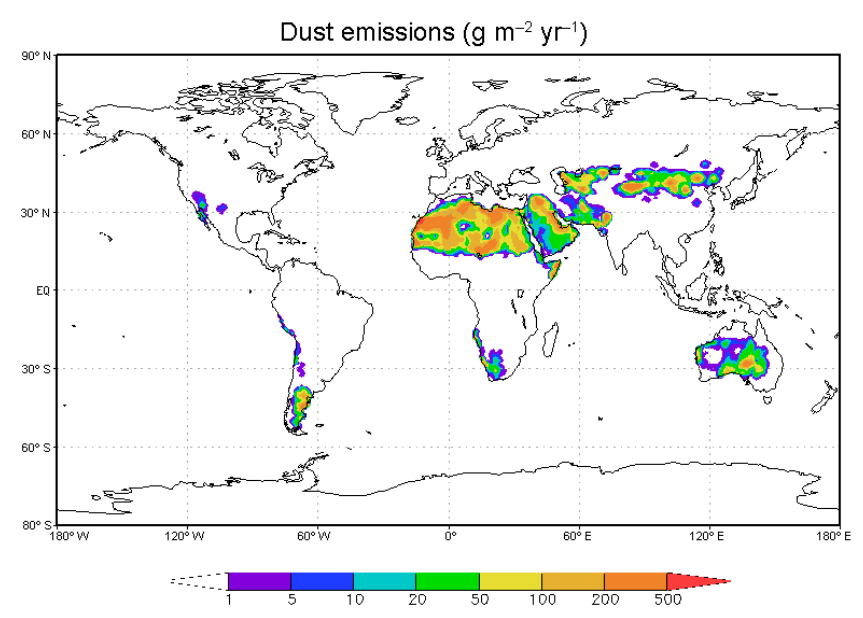

Figure 4. Annual dust emissions (in $\mathrm{g} \mathrm{m}^{-2} \mathrm{yr}^{-1}$ ) over the September 2012-September 2013 period.

aerosols are not radiatively coupled to AGCM is intended to facilitate aerosol modeling development in the near term. Once the prognostic aerosol capability reaches desired maturity level, this aerosol radiation decoupled configuration will be changed allowing the aerosol direct and semidirect radiative effects to be accounted for.

\section{NGAC results}

In this section, the results of operational NGAC V1.0 forecasts are presented. NCEP is currently working toward the second phase of NGAC implementation (Lu et al., 2016). The NGAC V2 includes full-suite of aerosols using nearreal-time smoke emissions from satellite fire products. The NGAC upgrade will produce total AOD, allowing us to evaluate NGAC results beyond dust-dominated regions. Efforts are underway to evaluate experimental NGAC V2 with other models (ICAP MME and GSFC's GEOS-5), in situ observations at AErosol RObotic NETwork (AERONET) sites throughout the globe, and aerosol retrievals from multiple satellites, including MODIS, Visible Infrared Imaging Radiometer Suite (VIIRS), and Cloud-Aerosol Lidar with Orthogonal Polarization (CALIOP). In this paper, only concise model results are presented as the paper mainly provides the programmatic aspects of NGAC development and implementation.

\subsection{Dust emissions and budget}

Figure 4 shows the annual dust emissions calculated from the first year NGAC V1.0 production (the September 2012September 2013 period). The similarity between the annual dust emissions and the dust source function (shown in Fig. 2) indicates that the source function is of central importance in determining dust uplifting relative to other parameters. In the Ginoux et al. (2001) dust emission scheme, a global scal-
Table 1. Global annual emissions, annual burden and lifetime for dust aerosols*.

\begin{tabular}{llll}
\hline & $\begin{array}{l}\text { Emissions } \\
\left(\mathrm{Tg} \mathrm{yr}^{-1}\right)\end{array}$ & $\begin{array}{l}\text { Burden } \\
(\mathrm{Tg})\end{array}$ & $\begin{array}{l}\text { Lifetime } \\
(\text { day })\end{array}$ \\
\hline NGAC V1.0 & 1980 & 21.9 & 4.3 \\
On-line GEOS4 & 1970 & 31.6 & 5.85 \\
Off-line GEOS4 & 3242 & 38.4 & 4.33 \\
Off-line GEOS & $1604-1956$ & $31-40$ & $6.6-7.3$ \\
AeroCom & $1123[514-4313]$ & $15.8[6.8-29.5]$ & $4.6[1.6-7.1]$ \\
\hline
\end{tabular}

* Note: the top number is the NGAC V1.0 results from September 2012-September 2013, the second number is the results of on-line GEOS4-GOCART simulations (Table 1 in Colarco et al., 2010), the third number is the results of off-line GEOS4-GOCART model (Table 1 in Colarco et al., 2010 which in turn is provided by Mian Chin using the off-line GEOS4-GOCART model al., 2010 which in turn is provided by Mian Chin using the off-line GEOS4-GOCART model
described in Chin et al., 2009), the fourth number is the results of off-line GEOS-GOCART model (Table 2 in Ginoux et al., 2001), and the fifth number is the average of the AeroCom models with the range of the models in parentheses (Table 3 in Huneeus et al., 2011).

ing factor ( $C$, equal to $1 \mu \mathrm{g} \mathrm{s}^{2} \mathrm{~m}^{-5}$ ) is used to scale total dust flux to yield a total emission about $1800-2000 \mathrm{Tg} \mathrm{yr}^{-1}$. This factor is adjusted to $0.375 \mu \mathrm{g} \mathrm{s}^{2} \mathrm{~m}^{-5}$ in GEOS-4/5 owing to differences in the GEOS-4 meteorology relative to previous versions of GEOS-DAS assimilated meteorology. As we adopted the on-line version of GOCART from GEOS4/5 into NEMS GFS, the scaling factor is reverted back to $1 \mu \mathrm{g} \mathrm{s}^{2} \mathrm{~m}^{-5}$ to account for the differences in AGCM and resolution (i.e., $0.25^{\circ}$ resolution for GEOS-5 and $\sim 1^{\circ}$ resolution for NEMS GFS).

Table 1 provides a summary of NGAC V1.0 calculated annual emission, burden, and lifetime (or atmospheric residence time) relative to other similar global aerosol models, including three versions of GOCART results and the models participating in the Aerosol Comparisons between Observations and Models (AeroCom) model intercomparison studies (http://aerocom.met.no/aerocomhome.html). The three GOCART results are from on-line GEOS4-GOCART (Colarco et al., 2010) and off-line GOCART CTM driven by two versions of GEOS DAS meteorological analyses (Ginoux et al., 2001; Chin et al., 2009).

Large difference (diversity) are found in emissions, burdens, and lifetimes within the AeroCom models, which is primarily related to the differences in the emission parameterizations, the particles sizes, the meteorological fields, and model configuration used in the individual models (Textor et al., 2006). The simulated total dust emissions, annual burden, and lifetime in NGAC V1.0 are within the range of the AeroCom models. The annual emissions are similar in NGAC V1.0 and on-line GEOS4-GOCART (1980 $\mathrm{Tg} \mathrm{yr}^{-1}$ versus $1970 \mathrm{Tg} \mathrm{yr}^{-1}$ ). In NGAC V1.0, the lifetime is about 1.5 days shorter than in on-line GEOS4-GOCART (4.3 days vs. 5.85 days) and the annual burden is about $30 \%$ lower $(21.9 \mathrm{Tg}$ vs. $31.6 \mathrm{Tg})$. The results suggest more efficient removal processes in NGAC V1.0 than in GEOS4. 


\subsection{Aerosol optical depth}

In this section, we present the results of NGAC V1.0 dust distributions. We first compare NGAC dust AOD to dust AOD from GEOS-5 and total AOD from MODIS onboard Terra. Figure 5 shows monthly-mean dust distributions over the subtropical Atlantic region at different seasons. The source regions over the Sahara and Sahel are clearly shown as well as the patterns of long-range dust transport. Trade winds steer African dust westward across the Atlantic ocean, covering vast areas of the North Atlantic and sometime reaching the Americas (e.g., the Caribbean, southeastern United States, Central America, and Amazon basin). This has implications for air quality, public health, climate, and biogeochemical cycle. For instance, about half of the annual dust supply to the Amazon basin is emitted from a single source in the Sahara, the Bodele depression (Koren et al., 2006).

While elevated dust off the western Africa coast is persistent through the seasons, the models and satellite observations show a clear latitudinal shift of the dust plume over the tropical Atlantic from winter to summer. This seasonal shift has been attributed to the movements of the Intertropical Convergence Zone (ITCZ) which occupies its southernmost location in winter and northernmost location in summer (Huser et al., 1997; Ginoux et al., 2001). The results are consistent with the seasonal cycle discussed in Knippertz and Todd (2012) in which detailed descriptions of meteorological processes controlling the emissions and transport of African dust are provided.

The comparison of model forecasts to L1.5 AERONET AOD at $550 \mathrm{~nm}$ for the 2013-2014 period at six stations is shown in Fig. 6. AERONET AOD at $550 \mathrm{~nm}$ is computed using logarithmic interpolation between AOD values at 440 and $675 \mathrm{~nm}$. We bin the AERONET observations within $1 \mathrm{~h}$ time windows centered at NGAC synoptic output times of 03:00, 06:00, 09:00, 12:00, 15:00, 18:00, 21:00, and 24:00 UTC. The calculation of monthly mean requires a minimum of 5 days with valid values. We show the comparison of the model AOD to AERONET observations, including the time series, a scatter plot, a fractional distribution histogram (PDF) of the model and observed AOD, and some statistics including mean biases, root mean square errors, linear fit parameters, and correlation coefficients. Among the six stations included in the comparison, three sites are located in dust-prone Sahara-Sahel region (Dakar, Ilorin, and Banizoumbou), one site is located in the dust-prone Middle East area (Sede Boker), and two sites are located in tropical Atlantic Ocean region (Cape Verde and La Parguera). The Dakar site is located in Senegal, northern Africa near the dust source region. The Ilorin site, located in Guinea Savanna zone, experiences dust and episodic smoke aerosols. The Banizoumhou site, located in the Sahel region, is influenced predominantly by dust transport from the Sahara. For the two ocean sites, Cape Verde is influenced by dust outflow from Saharan sources while La Parguera is influenced by long-range transport of Saharan dust. The Middle East site, Sede Boker, is located in the Negev desert of Israel and experiences mainly dust and urban aerosols. At these sites except for Ilorin, NGAC V1.0 simulations are found to capture the seasonal variability in the dust loading. Overall, NGAC V1.0 shows similar seasonal variability to and is well correlated with the AERONET observations.

\section{NGAC applications}

NGAC V1.0 provides two- and three-dimensional aerosol products at $1^{\circ} \times 1^{\circ}$ resolution on a global scale. Potential usage for these aerosol products includes, but is not limited to: AOD at $340 \mathrm{~nm}$ for UV index forecasts; AOD at $550 \mathrm{~nm}$ for multi-model ensemble and aerosol data assimilation; AOD at $860 \mathrm{~nm}$ for AVHRR SST retrievals; AOD at $11.1 \mu \mathrm{m}$ for the Atmospheric Infrared Sounder (AIRS) temperature retrievals; three-dimensional dust mixing ratios for atmospheric correction; dust column mass density, emission and removal fluxes for aerosol budget study; dust deposition fluxes for ocean productivity and dust surface mass concentrations for air quality. Here we present two examples of NGAC product applications.

\subsection{Multi-model ensemble}

The International Cooperative for Aerosol Prediction (ICAP), consisting of forecasting center model developers and remote sensing data providers, began meeting in April 2010 to discuss issues relevant to the operational aerosol forecasting (Benedetti, 2011; Reid et al., 2011). ICAP members created a developmental global multiple-model ensemble (MME) to explore probabilistic aerosol prediction and assess relative differences among models (Sessions et al., 2015). Consensus ICAP forecasting began in early 2011 and the experimental ICAP-MME became quasi-operational for public release in 2015. Current ICAP MME products include AOD ensemble from four complete aerosol forecast models from NRL, ECMWF, JMA, and GMAO, as well as three dust-only models from NCEP, UKMO, and BSC. Figure 7 shows the dust AOD from ICAP-MME (with seven members) and NGAC V1.0, valid at 12:00 UTC, 4 July 2015. Spatial pattern of dust loading from NGAC V1.0 is consistent with the ICAP-MME, with elevated dust AOD located in the Sahara, the Arabian Peninsula, and Asia as well as evident long-range trans-Atlantic transport of Saharan dust reaching the southeastern United States.

Dust forecasts from NGAC V1.0 also contribute to the regional multi-model ensemble produced by WMO Sand and Dust Storm Warning Advisory and Assessment System (SDS-WAS) Regional Center for northern Africa, the Middle East, and Europe, hosted at BSC, Spain (http://sds-was. aemet.es). Participation in ICAP-MME and WMO SDSWAS multi-model ensemble provides a continuous and inde- 

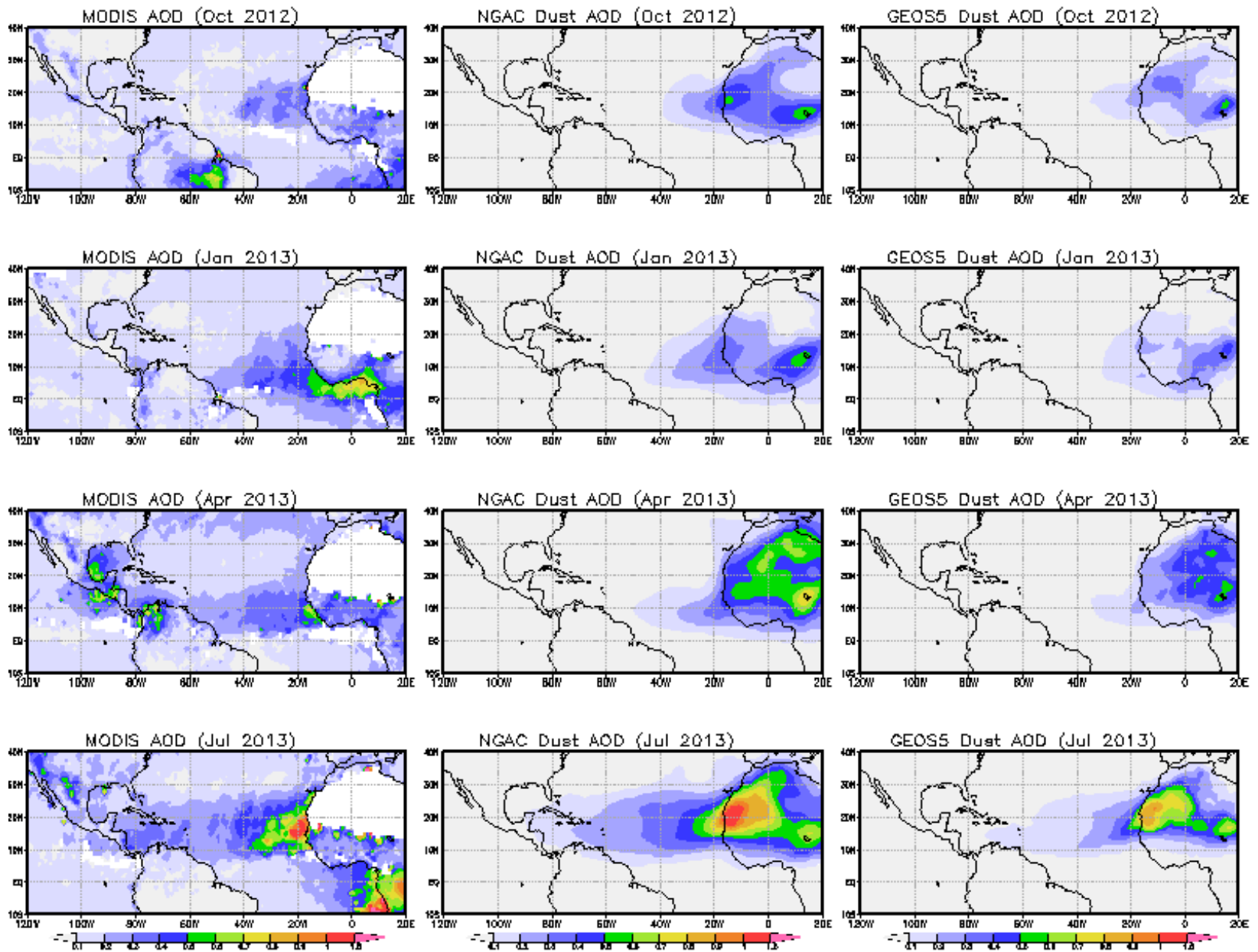

Figure 5. Comparisons of monthly-mean MODIS total AOD (left), NGAC V1.0 dust AOD (middle), and GEOS5 dust AOD (right) at $550 \mathrm{~nm}$ for October 2012, as well as January, April, and July 2013 periods.

pendent assessment of the quality of NCEP global dust products. Overall, NGAC V1.0 forecasts are found to be comparable to that produced by other domestic and international modeling centers.

\subsection{Dynamic lateral boundary conditions for regional models}

An example on using NGAC dust information to improve regional air quality forecasts is presented here. Under a NOAA-EPA partnership, NOAA is undertaking the responsibility to develop and maintain the National Air Quality Forecasting (AQF) system (Davidson et al., 2004). The AQF system is based on EPA Community Multi-scale Air Quality (CMAQ) model (Byun and Schere, 2006) driven by meteorological forecasts from NCEP North American Meso (NAM) Model (see the NAM webpage at http://www.emc. ncep.noaa.gov/?branch=NAM). Static lateral boundary conditions (LBCs) assuming no dust from outside the model boundary are currently used.
Two CMAQ runs are conducted for the July 2010 period. The baseline run uses static LBCs and the experimental run uses dynamic LBCs from NGAC V1.0. Figure 8 shows the observed and modeled surface particulate matter smaller than 2.5 micron $\left(\mathrm{PM}_{2.5}\right)$ at two AIRNOW stations in the southeast region. Table 2 presents the statistic results of the CMAQ compared to the EPA AIRNOW $\mathrm{PM}_{2.5}$. It is found that the incorporation of dynamic LBCs from NGAC V1.0 reduces model biases and improves correlation. Clearly, the inclusion of long-range dust transport through dynamic LBCs leads to significant improvements in CMAQ forecasts during dust intrusion episodes.

\section{Conclusions}

NASA/GMAO's GOCART aerosol module has been implemented into NEMS GFS at NCEP through NOAA/NCEPNASA/GSFC collaborations. While NGAC has the capability to forecast dust, sulfate, sea salt, and carbonaceous aerosols, the initial phase implementation is to establish dust- 

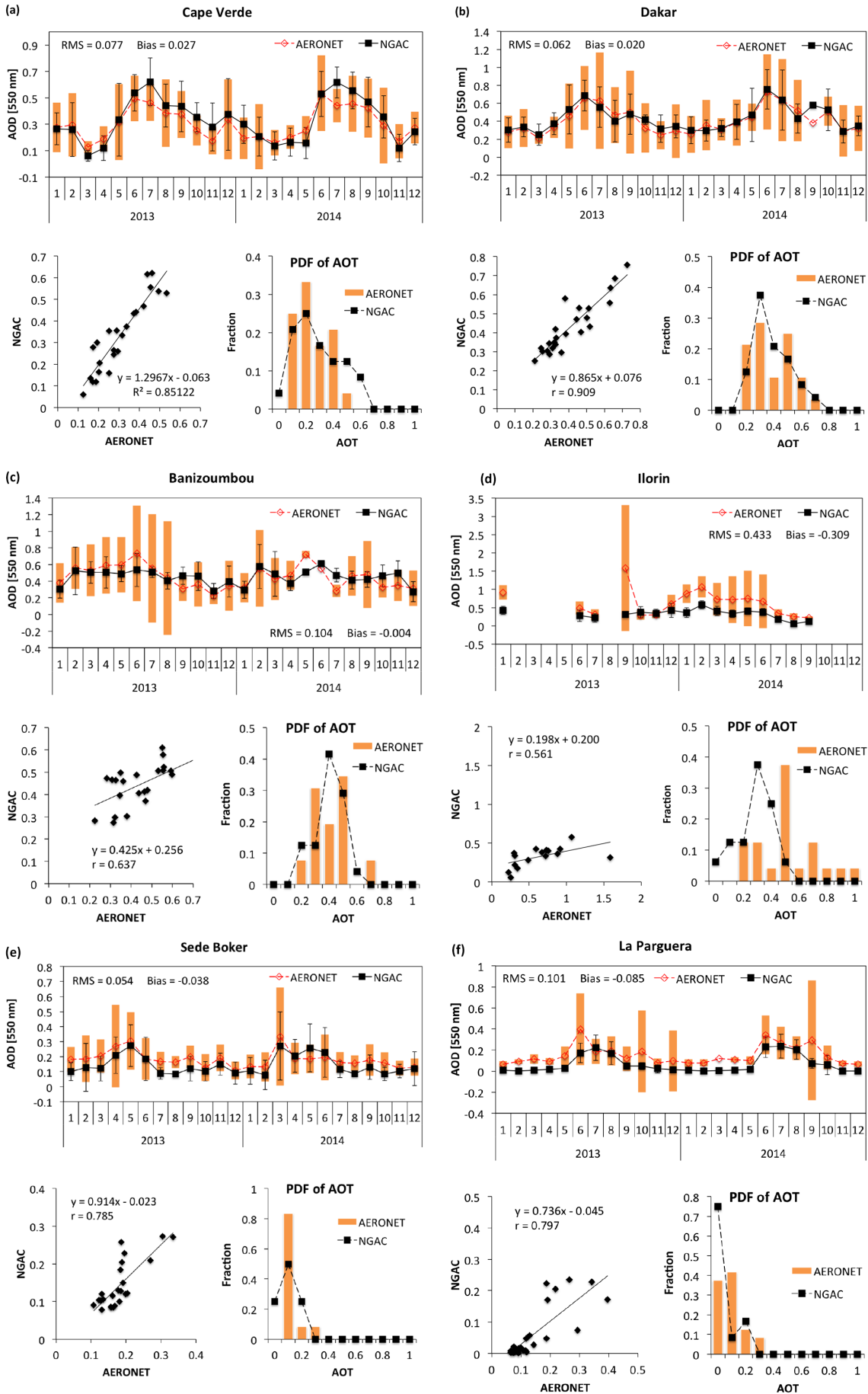

Figure 6. (a) NGAC V1.0 versus L1.5 AERONET $550 \mathrm{~nm}$ AOD comparisons at Cape Verde for the 2013-2014 period: a time series, scatterplot, and fractional distribution histogram. In the time series, the model monthly means and standard deviation about the mean are shown in the black symbols and lines. The AERONET monthly means and standard deviation about the mean are shown in the red shading and orange bars. In the PDF plot, the model is indicated by the black symbols and line, and the AERONET observations are indicated by orange bars. (b) NGAC V1.0 versus AERONET $550 \mathrm{~nm}$ AOD comparisons at Dakar for the 2013-2014 period: a time series, scatterplot, and fractional distribution histogram. (c) NGAC V1.0 vs. AERONET $550 \mathrm{~nm}$ AOD comparisons at Banizoumbou for the 2013-2014 period: a time series, scatterplot, and fractional distribution histogram. (d) NGAC V1.0 vs. AERONET $550 \mathrm{~nm}$ AOD comparisons at Ilorin for the 2013-2014 period: a time series, scatterplot, and fractional distribution histogram. (e) NGAC V1.0 vs. AERONET 550 nm AOD comparisons at Sede Boker for the 2013-2014 period: a time series, scatterplot, and fractional distribution histogram. (f) NGAC V1.0 vs. AERONET $550 \mathrm{~nm}$ AOD comparisons at La Parguera for the 2013-2014 period: a time series, scatterplot, and fractional distribution histogram. 
Table 2. Statistic results comparing CMAQ model results with EPA AIRNOW PM 2.5 . The mean bias (MB) and correlation $(R)$ are calculated for the baseline run using static LBCs and the experimental run using NGAC LBCs.

\begin{tabular}{lll}
\hline Domain/period & CMAQ baseline & CMAQ experimental \\
\hline Whole domain, 1 July-3 August & $\mathrm{MB}=-2.82, R=0.42$ & $\mathrm{MB}=-0.88, R=0.44$ \\
South of $38^{\circ} \mathrm{N}$, east of $105^{\circ} \mathrm{W}$ 1 July-3 August & $\mathrm{MB}=-4.54, R=0.37$ & $\mathrm{MB}=-1.76, R=0.41$ \\
Whole domain, 18-30 July & $\mathrm{MB}=-2.79, R=0.31$ & $\mathrm{MB}=-0.33, R=0.37$ \\
South of $38^{\circ} \mathrm{N}$, east of $105^{\circ} \mathrm{W}$ 18-30 July & $\mathrm{MB}=4.79, R=0.27$ & $\mathrm{MB}=-0.46, R=0.41$ \\
\hline
\end{tabular}
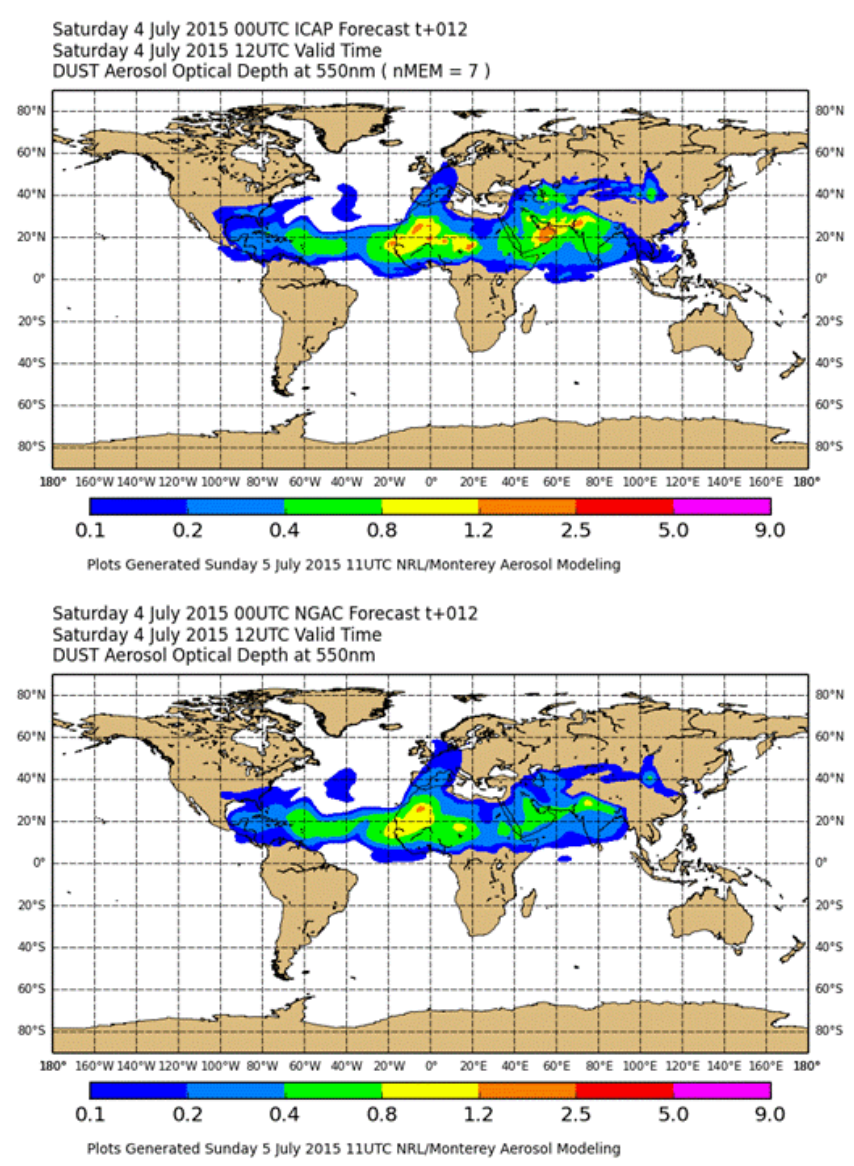

Figure 7. Dust AOD valid at 12:00 UTC, 4 July 2015 for ICAP multi-model ensemble (top) and NGAC V1.0 (bottom). The ensemble is based on seven members, including the models from NCEP (NGAC V1.0), GMAO, ECMWF, NRL, JMA, UKMO, and BSC. These figures are produced by the Naval Research Laboratory.

only numerical guidance. NGAC Version 1.0, implemented in September 2012, provides the first operational global dust forecasting capability at NOAA. Its AOD product has been incorporated into global and regional multi-model ensemble products (ICAP and WMO SDS-WAS, respectively) in quasi-operational mode.

The NGAC V1.0 dust forecasts are routinely verified using AOD observations from space-borne MODIS and groundbased AERONET. NGAC V1.0 results are also compared
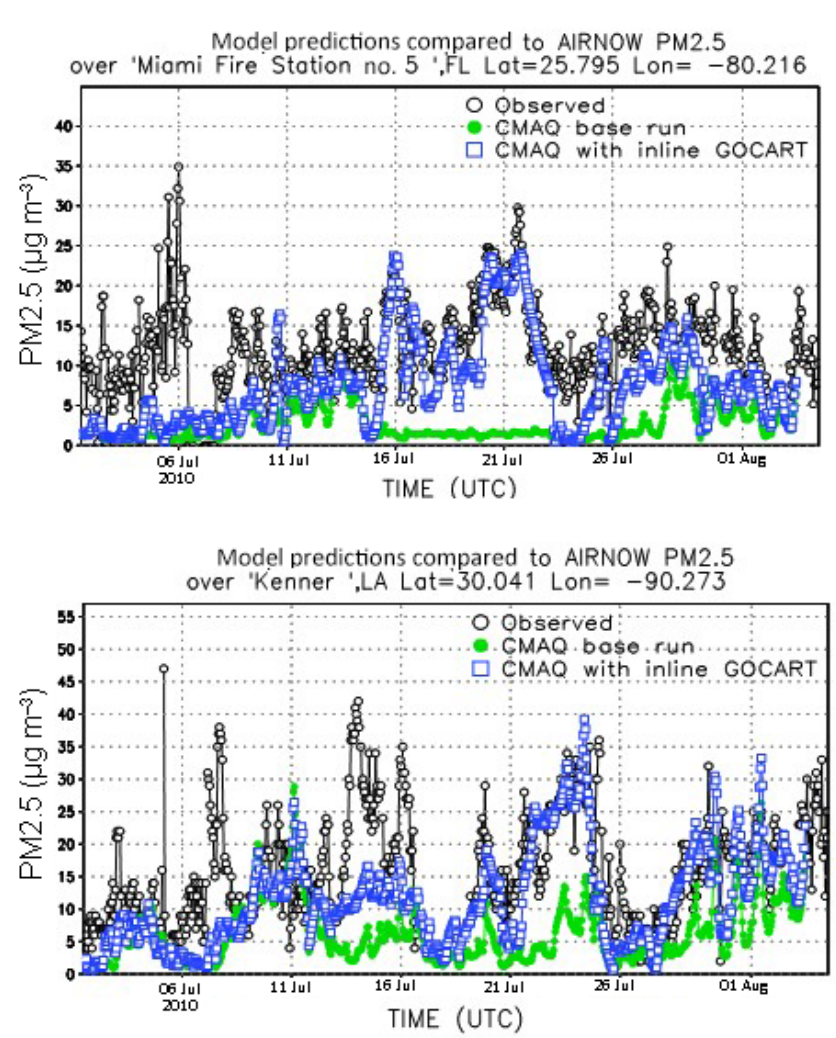

Figure 8. Time series of $\mathrm{PM}_{2.5}$ from EPA AIRNOW observations (black dot), CMAQ baseline run using static LBCs (green dot), and CMAQ experimental run using NGAC LBCs (blue square) at Miami, FL (top panel) and Kenner, LA (bottom panel).

with those from other similar aerosol models. It is shown that the NGAC V1.0 simulated spatial distributions and seasonal variations are consistent with the observations. In addition, the emissions, burdens, and lifetime of dust aerosols in NGAC V1.0 are within the range of similar aerosol models.

While the initial NGAC implementation is limited in its scope (a dust-only system without aerosol data assimilation), it laid the ground work for various aerosol-related applications. Future operational benefits associated with the global aerosol forecasting system at NOAA include the following:

- Enable operational global short-range multi-species aerosol prediction. 
- Provide the first step toward an operational aerosol data assimilation capability at NCEP.

- Allow aerosol impacts on medium-range weather forecasts to be considered.

- Provide global aerosol information for various applications, including satellite radiance data assimilation, satellite retrievals, SST analysis, and UV Index forecasts.

- Allow NCEP to explore aerosol-cloud-climate interaction in the Climate Forecast System (CFS), as GFS is the atmosphere model of the CFS.

- Provide lateral aerosol boundary conditions for regional aerosol forecast system.

\section{Data and code availability}

Products from the NCEP operational production suite are distributed and accessible to general users, free of charge, in real-time (typically no later than $3 \mathrm{~h}$ after the data are created) at NOAA Operational Model Archive and Distribution System (NOMADS). Source code as well as relevant run scripts, parameters, and fixed field files can be obtained from NCEP Central Operations (NCO) ftp site at the following location: http://www.nco.ncep.noaa.gov/pmb/codes/nwprod/ngac.
The NGAC V1.0 output is available in GRIdded Binary Version 2 (GRIB2) format on $1^{\circ} \times 1^{\circ}$ degree grid, with 3 hourly output up to $120 \mathrm{~h}$. Users can access the NGAC V1.0 digital products from NOMADS at the following location:

http://nomads.ncep.noaa.gov/pub/data/nccf/com/ngac

NGAC V1.0 output instantaneous values of threedimensional dust mixing ratios for five particle sizes with effective radius at $1,1.8,3,6$, and 10 micron. The model also output time-averaged two-dimensional diagnostics fields relevant to aerosol budget, such as emission fluxes. These aerosol fields are written out at GFS native Gaussian grid, and post-processed to GRIB 2 format and regular $1^{\circ} \times 1^{\circ}$ degree grid. Dust AOD at $550 \mathrm{~nm}$ and other selected spectral is calculated from instantaneous dust distributions with aerosol optical properties based on Chin et al. (2002). NGAC V1.0 GRIB2 output files and their contents are listed in the Appendix A. v1.0.0 


\section{Appendix A: NGAC output}

Output files and their contents for NGAC V1.0 (Q4FY12 Implementation)

(1) ngac.t00z.a2df $\$ H R$, where $\mathrm{HR}=00,03, \ldots, 120$ :

2-D products including

AER_OPT_DEP_at550: dust aerosol optical depth at $550 \mathrm{~nm}$ (dimensionless)

CR_AER_SFC_MASS_CON: coarse mode surface mass concentration $\left(\mathrm{kg} \mathrm{m}^{-3}\right)$

FN_AER_SFC_MASS_CON: fine mode surface mass concentration $\left(\mathrm{kg} \mathrm{m}^{-3}\right)$

CR_AER_COL_MASS_DEN: coarse mode column mass density $\left(\mathrm{kg} \mathrm{m}^{-2}\right)$

FN_AER_COL_MASS_DEN: fine mode column mass density $\left(\mathrm{kg} \mathrm{m}^{-2}\right)$

DUST_EMISSION_FLUX: dust emission fluxes $\left(\mathrm{kg} \mathrm{m}^{-2} \mathrm{~s}^{-1}\right)$

DUST_SEDIMENTATION_FLUX: dust sedimentation fluxes $\left(\mathrm{kg} \mathrm{m}^{-2} \mathrm{~s}^{-1}\right)$

DUST_DRY_DEPOSITION_FLUX: dust dry deposition fluxes $\left(\mathrm{kg} \mathrm{m}^{-2} \mathrm{~s}^{-1}\right)$

DUST_WET_DEPOSITION_FLUX: dust wet deposition fluxes $\left(\mathrm{kg} \mathrm{m}^{-2} \mathrm{~s}^{-1}\right)$

(2) ngac.t00z.a3df $\$ H R$, where $H R=00,03, \ldots, 120$ :

3-D products at model levels including

PRES: pressure $(\mathrm{Pa})$

RH: relative humidity (\%)

TEMP: temperature $(\mathrm{K})$

DUST1: dust bin1 (0.1-1 micron) mixing ratio $\left(\mathrm{kg} \mathrm{kg}^{-1}\right)$

DUST2: dust bin2 (1-1.8 micron) mixing ratio $\left(\mathrm{kg} \mathrm{kg}^{-1}\right)$

DUST3: dust bin3 (1.8-3 micron) mixing ratio $\left(\mathrm{kg} \mathrm{kg}^{-1}\right)$

DUST4: dust bin4 (3-6 micron) mixing ratio $\left(\mathrm{kg} \mathrm{kg}^{-1}\right)$

DUST5: dust bin5 (6-10 micron) mixing ratio $\left(\mathrm{kg} \mathrm{kg}^{-1}\right)$

(3) ngac.t00z.aod_\$NM, where NM $=11 \mathrm{p} 1 \mathrm{um}, 1 \mathrm{p} 63 \mathrm{um}$, $340 \mathrm{~nm}, 440 \mathrm{~nm}, 550 \mathrm{~nm}, 660 \mathrm{~nm}, 860 \mathrm{~nm}$ :

Aerosol optical depth (dimensionless) at specified wavelengths (11.1, 1.63, 0.34, 0.44, 0.55, 0.66, and 0.86 micron) 
Acknowledgements. The NGAC project has been supported by NASA Applied Science Program and NOAA-NASA-DOD Joint Center for Satellite Data Assimilation. The authors thank the principal investigators of the AERONET sites (Didier Tanre for Cape Verde, Dakar, and Banizoumbou, Rachel Pinker for Ilorin, Brent Holben for La Parguera, and Arnon Karnieli for Sede Boker) for the efforts in establishing and maintaining AERONET sites. Brent Holben leads the AERONET program and provided access to near-real-time L1.5 data set. The authors also appreciate the multi-model ensemble work done by the NRL (for ICAP) and BSC (for WMO SDS-WAS NA-ME-E Regional Center). The lead author C.-H. Lu is grateful for technical help and/or scientific input from her NCEP EMC colleagues, Wei-Yu Yang, Perry Shafran, Ho-Chun Huang, and Yuqiu Zhu. She also thanks her NCEP NCO colleagues for transitioning pre-operational NGAC V1.0 system into NCEP production, including Simon Hsiao, Xiaoxue Wang, Christine Caruso Magee, Jeff Ator, Boi Vuong, Rebecca Cosgrove and Daniel Starosta. The pre-implementation evaluation by Walter Sessions, Nick Nalli, Andy Harris, Craig Long, Gary Votaw, and Jeral Estupinan is also greatly appreciated.

Edited by: R. Sander

\section{References}

Albrecht, B. A.: Aerosols, cloud microphysics and fractional cloudiness, Science, 245, 1227-1230, 1989.

Andreae, M. O. and Crutzen, P. J.: Atmospheric Aerosols: biogeochemical sources and role in atmospheric chemistry, Science, 276, 1052-1054, 1997.

Basart, S., Pérez, C., Nickovic, S., Cuevas, E., and Baldasano, J. M.: Development and evaluation of the BSCDREAM8b dust regional model over Northern Africa, the Mediterranean and the Middle East, Tellus B, 64, 18539, doi:10.3402/tellusb.v64i0.18539, 2012.

Benedetti, A., Morcrette, J.-J., Boucher, O., Dethof, A., Engelen, R. J., Fisher, M., Flentjes, H., Huneeus, N., Jones, L., Kaiser, J. W., Kinne, S., Mangold, A., Razinger, M., Simmons, A. J., Suttie, M., and the GEMS-AER team: Aerosol analysis and forecast in the European Centre for Medium-Range Weather Forecasts Integrated Forecast System: 2. Data assimilation, J. Geophys. Res., 114, D13205, doi:10.1029/2008JD011115, 2009.

Benedetti, A., Reid, J. S., and Colarco, P. R.: International Cooperative for Aerosol Prediction (ICAP) Workshop On Aerosol Forecast Verification, B. Am. Meteorol. Soc., 92, ES48-ES53, doi:10.1175/BAMS-D-11-00105.1, 2011.

Benedetti, A., Baldasano, J. M., Basart, S., Benincasa, F., Boucher, O., Brooks, M., Chen, J.-P., Colarco, P. R., Gong, S., Huneeus, N., Jones, L. T., Lu, S., Menut, L., Morcrette, J.-J., Mulcahy, J., Nickovic, S., Perez Garcia-Pando, C., Reid, J. S., Sekiyama, T. T., Tanaka, T. Y., Terradellas, E., Westphal, D. L., Zhang, X.-Y., and Zhou, C.-H.: Operational dust forecasting, Chapter 10 in: Mineral Dust: a Key Player in the Earth System, edited by: Knippertz, P., and Stuut, J.-B., Springer Publications, Dodrecht, the Netherlands, ISBN 978-94-017-8977-6, 121-148, doi:10.1007/978-94-017-8978-3_10, 2014.

Bian, H., Chin, M., Kawa, S. R., Yu, H., and Diehl, T.: Multi-scale carbon monoxide and aerosol correlations from MOPITT and
MODIS satellite measurements and GOCART model: implication for their emissions and atmospheric evolutions, J. Geophys. Res., 115, D07302, doi:10.1029/2009JD012781, 2010.

Black, T., Juang, H. M. H., Yang, W. Y., and Iredell, M.: An ESMF framework for NCEP operational models, in: 22nd Conference on Weather Analysis and Forecasting/18th Conference on $\mathrm{Nu}-$ merical Weather Prediction, Park City, UT, USA, 25-29 June 2007, Ameri. Met. Soc., J3.1, 2007.

Black, T., Juang, H. M. H., and Iredell, M.: The NOAA Environmental Modeling System at NCEP, Preprints, 23rd Conference on Weather Analysis and Forecasting/19th Conference on $\mathrm{Nu}$ merical Weather Prediction, Omaga, NE, USA, 1-5 June 2009, Ameri. Met. Soc., 2 A.6, 2009.

Byun, D. W. and Schere, K. L.: Review of the governing equations, computational algorithms, and other components of the Models3 Community Multiscale Air Quality (CMAQ) modeling system, Appl. Mech. Rev., 59, 51-77, 2006.

Chen, Y., Mills, S., Street, J., Golan, D., Post, A., Jacobson, M., and Paytan, A.: Estimates of atmospheric dry deposition and associated input of nutrients to Gulf of Aqaba seawater, J. Geophys. Res., 112, D04309, doi:10.1029/2006JD007858, 2007.

Chin, M., Savoie, D. L., Huebert, B. J., Bandy, A. R., Thornton, D. C., Bates, T. S., Quinn, P. K., Saltzman, E. S., and De Bruyn,W. J.: Atmospheric sulfur cycle in the global model GOCART: comparison with field observations and regional budgets, J. Geophys. Res., 105, 24689-24712, 2000.

Chin, M., Ginoux, P., Kinne, S., Torres, O., Holben, B. N., Duncan, B. N., Martin, R. V., Logan, J. A., Higurashi, A., and Nakajima, T.: Tropospheric aerosol optical thickness from the GOCART model and comparisons with satellite and sunphotometer measurements, J. Atmos. Sci., 59, 461-483, 2002.

Chin, M., Ginoux, P., Lucchesi, R., Huebert, B., Weber, R., Anderson, T., Masonis, S., Blomquist, B., Bandy, A., and Thornton, D.: A global aerosol model forecast for the ACEAsia field experiment, J. Geophys. Res., 108, 8654, doi:10.1029/2003JD003642, 2003.

Chin, M., Chu, D. A., Levy, R., Remer, L. A., Kaufman, Y. J., Holben, B. N., Eck, T., and Ginoux, P.: Aerosol distribution in the Northern Hemisphere during ACE-Asia: results from global model, satellite observations, and sunphotometer measurements, J. Geophys. Res., 109, D23S90, doi:10.1029/2004JD004829, 2004.

Chin, M., Diehl, T., Ginoux, P., and Malm, W.: Intercontinental transport of pollution and dust aerosols: implications for regional air quality, Atmos. Chem. Phys., 7, 5501-5517, doi:10.5194/acp7-5501-2007, 2007.

Chin, M., Diehl, T., Dubovik, O., Eck, T. F., Holben, B. N., Sinyuk, A., and Streets, D. G.: Light absorption by pollution, dust, and biomass burning aerosols: a global model study and evaluation with AERONET measurements, Ann. Geophys., 27, 3439-3464, doi:10.5194/angeo-27-3439-2009, 2009.

Colarco, P., Schoeberl, M., Doddridge, B., Marufu, L., Torres, O., and Welton, E.: Transport of smoke from Canadian forest fires to the surface near Washington DC, J. Geophys. Res., 109, D06203, doi:10.1029/2003JD004248, 2004.

Colarco, P., da Silva, A., Chin, M., and Diehl, T.: Online simulations of global aerosol distributions in the NASA GEOS-4 model and comparisons to satellite and ground-based aerosol optical depth, 
J. Geophys. Res., 115, D14207, doi:10.1029/2009JD012820, 2010.

Darmenov, A. and da Silva, A. M.: The Quick Fire Emissions Dataset (QFED) - Documentation of versions 2.1, 2.2 and 2.4, NASA Technical Report Series on Global Modeling and Data Assimilation, NASA/TM-2015-104606, Vol. 38, 211 pp., available at: http://gmao.gsfc.nasa.gov/pubs/tm/, last access: 18 December 2015.

Davidson, P. M., Seaman, N., Schere, K., Wayland, R. A., Hayes, J. L., and Carey, K. F.: National air quality forecasting capability: first steps toward implementation, in: Proceedings of Sixth Conf. on Atmos. Chem., Ameri. Met. Soc., Seattle, WA, USA, 10-16 January 2004, J2.10, 2004.

DeFries, R. S. and Townshend, J. R. G.: NDVI-derived land cover classification at global scale, Int. J. Remote Sens., 15, 35673586, 1994.

Dickerson, R. R., Kondragunta, S., Stenchikov, G., Civerolo, K. L., Doddrige, B. G., and Holben, B. N.: The impact of aerosols on solar ultraviolet radiation and photochemical smog, Science, 278, 827-830, 1997.

Duce, R. A.: The atmospheric input of trace species to the world ocean, Global Biogeochem. Cy., 5, 193-259, 1991.

Fan, J., Rosenfeld, D., Yang, Y., Zhao, C., Leung, L. R., and Li, Z.: Substantial contribution of anthropogenic air pollution to catastrophic floods in Southwest China, Geophys. Res. Lett., 42, 6066-6075, doi:10.1002/2015GL064479, 2015.

Ginoux, P., Chin, M., Tegen, I., Prospero, J., Holben, B., Dubovik, O., and Lin, S.-J.: Sources and global distributions of dust aerosols simulated with the GOCART model, J. Geophys. Res., 106, 20255-20273, 2001.

Ginoux, P., Prospero, J., Torres, O., and Chin, M.: Long-term simulation of dust distribution with the GOCART model: correlation with the North Atlantic Oscillation, Environ. Modell. Softw., 19, 113-128, 2004.

Han, J. and Pan, H.-L.: Revision of convection and vertical diffusion schemes in the NCEP global forecast system, Weather Forecast., 26, 520-533, 2011.

Haywood, J. M., Allan, R. P., Culverwell, I., Slingo, T., Milton, S., Edwards, J., and Clerbaux, N.: Can desert dust explain the outgoing longwave radiation anomaly over the Sahara during July 2003?, J. Geophys. Res., 110, D05105, doi:10.1029/2004JD005232, 2005.

Herbener, S. R., van den Heever, S. C., Carrió, G. G., Saleeby, S. M., William, R., and Cotton, W. R.: Aerosol indirect effects on idealized tropical cyclone dynamics. J. Atmos. Sci., 71, 20402055, doi:10.1175/JAS-D-13-0202.1, 2014.

Hess, M., Koepke, P., and Schult, I.: Optical properties of aerosols and clouds: the software package OPAC, B. Am. Meteorol. Soc., 79, 831-844, 1998.

Huneeus, N., Schulz, M., Balkanski, Y., Griesfeller, J., Prospero, J., Kinne, S., Bauer, S., Boucher, O., Chin, M., Dentener, F., Diehl, T., Easter, R., Fillmore, D., Ghan, S., Ginoux, P., Grini, A., Horowitz, L., Koch, D., Krol, M. C., Landing, W., Liu, X., Mahowald, N., Miller, R., Morcrette, J.-J., Myhre, G., Penner, J., Perlwitz, J., Stier, P., Takemura, T., and Zender, C. S.: Global dust model intercomparison in AeroCom phase I, Atmos. Chem. Phys., 11, 7781-7816, doi:10.5194/acp-11-7781-2011, 2011.

Husar, R. B., Prospero, J. M., and Stowe, L. L.: Characterization of tropospheric aerosols over the oceans with the NOAA ad- vanced very high resolution radiometer optical thickness operational products, J. Geophys. Res., 102, 16889-16909, 1997.

Jaffe, D., McKendry, I., Anderson, T., and Price, H.: Six "new" episodes of trans-Pacific transport of air pollutants, Atmos. Environ., 37, 391-404, 2003.

Jones, D., Robarts, D. L., and Slingo, A.: A climate model study of indirect radiative forcing by anthropogenic sulphate aerosols, Nature, 370, 450-453, 1994.

Kim, D., Chin, M., Bian, H., Tan, Q., Brown, M. E., Zheng, T., You, R., Diehl, T., Ginoux, P., and Kucsera, T.: The effect of the dynamic surface bareness to dust source function, emission, and distribution, J. Geophys. Res., 118, 1-16, doi:10.1029/2012JD017907, 2013.

Knippertz, P. and Todd, M. C.: Mineral dust aerosols over the Sahara: meteorological controls on emission and transport and implications for modeling, Rev. Geophys., 50, RG1007, doi:10.1029/2011RG000362, 2012.

Koren, I., Kaufman, Y. J., Washington, R., Todd, M. C., Rudich, Y., Vanderlei Martins, J., and Resenfeld, D.: The Bodele depressions: a single spot in the Sahara that provides most of the mineral dust to the Amazon forecast, Environ. Res. Lett., 1, 014005 , doi:10.1088/1748-9326/1/1/014005, 2006.

Lohmann, U., Feichter, J., Penner, J., and Leaitch, R.: Indirect effect of sulfate and carbonacerous aerosols: a mechanistic treatment, J. Geophys. Res., 105, 12193-12206, 2000.

Lu, S., Huang, H.-C., Hou, Y.-T., Tang, Y., McQueen, J., da Silva, A., Chin, M., Joseph, E., and Stockwell, W.: Development of NCEP Global Aerosol Forecasting System: an overview and its application for improving weather and air quality forecasts, in: NATO Science for Peace and Security Series: Air Pollution Modelling and Its Application XX, Springer Publications, Dordrecht, the Netherlands, ISBN 978-90-481-3810-4, 451-454, doi:10.1007/978-90-481-3812-8, 2010.

Lu, S., da Silva, A., Chin, M., Wang, J., Moorthi, S., Juang, H., Chuang, H.-Y., Tang, Y., Jones, L., Iredell, M., and McQueen, J.: The NEMS GFS Aerosol Component: NCEP's Global Aerosol Forecast System, NCEP Office Note 472, Washington DC, USA, 26 pp., available at: http://www.lib.ncep.noaa.gov/ ncepofficenotes/2010s/ (last access: 18 December 2015), 2013.

Lu, S., Wang, J., Bhattacharjee, P., Zhang, X., Kondragunta, S., da Silva, A., McQueen, J., Moorthi, S., Hou, Y., and Tallapragada, V.: The implementation of NEMS GFS Aerosol Component (NGAC) version 2: Global aerosol forecasting at NCEP using satellite-based smoke emissions, 5-8, Joint Center for Satellite Data Assimilation Quarterly, 53, available at: http: //www.jcsda.noaa.gov/news.php (last access: 24 April 2016), doi:10.7289/V50C4SS7, 2016.

Mitchell Jr., J.: The effect of atmospheric aerosols on climate with special references to temperature near the earth's surface, J. Appl. Meteorol., 10, 703-714, 1971.

Moorthi, S. and Suarez, M. J.: Relaxed Arakawa-Schubert: a parameterization of moist convection for general circulation models, Mon. Weather Rev., 120, 978-1002, 1992.

Moorthi, S. and Suarez, M. J.: Documentation of Version 2 of Relaxed Arakawa-Schubert Cumulus Parameterization With Moist Downdrafts, NOAA Technical report NWS/NCEP 99-01, NOAA/NCEP, College Park, MD, USA, 44 pp., 1999.

Morcrette, J.-J., Boucher, O., Jones, L., Salmond, D., Bechtold, P., Beljaars, A., Benedetti, A., Bonet, A., Kaiser, J. W., Razinger, 
M., Schulz, M., Serrar, S., Simmons, A. J., Sofiev, M., Suttie, M., Tompkins, A. M., and Untch, A.: Aerosol analysis and forecast in the European Centre for Medium-Range Weather Forecasts Integrated Forecast System: forward modeling, J. Geophys. Res., 114, D06206, doi:10.1029/2008JD011235, 2009.

Mulcahy, J. P., Walters, D. N., Bellouin, N., and Milton, S. F.: Impacts of increasing the aerosol complexity in the Met Office global numerical weather prediction model, Atmos. Chem. Phys., 14, 4749-4778, doi:10.5194/acp-14-4749-2014, 2014.

Pérez, C., Nickovic, S., Pejanovic, G., Baldasano, J. M., and Ozsoy, E.: Interactive dust radiation modeling: a step to improve weather forecasts, J. Geophys. Res., 11, D16206, doi:10.1029/2005JD006717, 2006.

Pérez, C., Haustein, K., Janjic, Z., Jorba, O., Huneeus, N., Baldasano, J. M., Black, T., Basart, S., Nickovic, S., Miller, R. L., Perlwitz, J. P., Schulz, M., and Thomson, M.: Atmospheric dust modeling from meso to global scales with the online NMMB/BSC-Dust model - Part 1: Model description, annual simulations and evaluation, Atmos. Chem. Phys., 11, 1300113027, doi:10.5194/acp-11-13001-2011, 2011.

Pöschl, U.: Atmospheric aerosols: composition, transformation, climate, and health effects, Angew. Chem. Int. Edit., 44, 75207540, doi:10.1002/anie.200501122, 2005.

Prospero, J.: Long-term measurements of the transport of African mineral dust to the southeastern United States: implications for regional air quality, J. Geophys. Res., 104, 15917-15927, 1999.

Prospero, J. M., Barrett, K., Church, T., Dentener, F., Duce, R. A., Galloway, J. N., Levy II, H., Moody, J., and Quinn, P.: Atmospheric deposition of nutrients to the North Atlantic basin, Biogeochemistry, 35, 27-73, 1996.

Ramanathan, V., Crutzen, P. J., Kiehl, J. T., and Rosenfeld, D.: Aerosol, climate, and the hydrological cycle, Science, 294, 2119-2124, 2001.

Reid, J. S., Benedetti, A., Colarco, P. R., and Hansen, J. A.: International Operational Aerosol Observability Workshop, B. Am. Meteorol. Soc., 92, ES21-ES24, doi:10.1175/2010BAMS3183.1, 2011.

Rodwell, M. J. and Jung, T.: Understanding the local and global impacts of model physics changes: an aerosol example, Q. J. Roy. Meteor. Soc., 134, 1479-1497, doi:10.1002/qj.298, 2008.

Rosenfeld, D., Woodley, W. L., Khain, A., Cotton, W. R., Carrió, G., Ginis, I., and Golden, J. H.: Aerosol effects on microstructure and intensity of tropical cyclones, B. Am. Meteorol. Soc., 93, 987-1001, 2012.

Saide, P. E., Spak, S. N., Pierce, R. B., Otkin, J. A., Schaack, T. K., Heidinger, A. K., da Silva, A. M., Kacenelenbogen, M., Redemann, J., and Carmichael, G. R.: Central American biomass burning smoke can increase tornado severity in the U.S., Geophys. Res. Lett., 42, 956-965, doi:10.1002/2014GL062826, 2015.

Sessions, W. R., Reid, J. S., Benedetti, A., Colarco, P. R., da Silva, A., Lu, S., Sekiyama, T., Tanaka, T. Y., Baldasano, J. M., Basart, S., Brooks, M. E., Eck, T. F., Iredell, M., Hansen, J. A., Jorba, O. C., Juang, H.-M. H., Lynch, P., Morcrette, J.-J., Moorthi, S., Mulcahy, J., Pradhan, Y., Razinger, M., Sampson, C. B., Wang, J., and Westphal, D. L.: Development towards a global operational aerosol consensus: basic climatological characteristics of the International Cooperative for Aerosol Prediction Multi-
Model Ensemble (ICAP-MME), Atmos. Chem. Phys., 15, 335362, doi:10.5194/acp-15-335-2015, 2015.

Tanaka, T. Y., Orito, K., Sekiyama, T. T., Shibata, K., Chiba, M., and Tanaka, H.: MASINGAR, a global tropospheric aerosol chemical transport model coupled with MRI/JMA98 GCM: model description, Pap. Meteorol. Geophys., 53, 119-138, 2003.

Textor, C., Schulz, M., Guibert, S., Kinne, S., Balkanski, Y., Bauer, S., Berntsen, T., Berglen, T., Boucher, O., Chin, M., Dentener, F., Diehl, T., Easter, R., Feichter, H., Fillmore, D., Ghan, S., Ginoux, P., Gong, S., Grini, A., Hendricks, J., Horowitz, L., Huang, P., Isaksen, I., Iversen, I., Kloster, S., Koch, D., Kirkevåg, A., Kristjansson, J. E., Krol, M., Lauer, A., Lamarque, J. F., Liu, X., Montanaro, V., Myhre, G., Penner, J., Pitari, G., Reddy, S., Seland, $\varnothing .$, Stier, P., Takemura, T., and Tie, X.: Analysis and quantification of the diversities of aerosol life cycles within AeroCom, Atmos. Chem. Phys., 6, 1777-1813, doi:10.5194/acp-6-1777-2006, 2006.

Tompkins, A. M., Cardinali, C., Morcrette, J. J., and Rodwell, M.: Influence of aerosol climatology on forecasts of the African Easterly Jet, Geophys. Res. Lett., 32, L10801, doi:10.1029/2004GL022189, 2005.

Twomey, S.: Pollution and the planetary albedo, Atmos. Environ., 8, 1251-1256, 1974.

Wang, J., van den Heever, S. C., and Reid, J. S.: Central American biomass burning aerosols and severe weather over the south central United States, Environ. Res. Lett., 4, 015003, doi:10.1088/1748-9326/4/1/015003, 2009.

Wang, Y., Wang, M., Zhang, R., Ghan, S., Lin, Y., Hu, J., Pan, B., Levy, M., Jiang, J., and Molina, M.: Assessing the effects of anthropogenic aerosols on Pacific storm track using a multiscale global climate model, P. Natl. Acad. Sci. USA, 111, 6894-6899, doi:10.1073/pnas.1403364111, 2014.

Westphal, D. L., Curtis, C. A., Liu, M., and Walker, A. L.: Operational aerosol and dust storm forecasting, in: WMO/GEO Expert Meeting on an International Sand and Dust Storm Warning System, IOP Conf. Series: Earth and Environ. Science, 7-9 November 2007, Barcelona Supercomputing Center (BSC), Barcelona, Spain, 7, doi:10.1088/1755-1307/7/1/012007, 2009.

Woodward, S.: Modeling the atmospheric life cycle and radiative impact of mineral dust in the Hadley Centre climate model, J. Geophys. Res., 106, 18155-18166, doi:10.1029/2000JD900795, 2001.

Woodward, S.: Mineral Dust in HadGEM2, Tech. Note 87, Hadley Cent., Met Office, Exeter, UK, 2011.

Zhang, J., Reid, J. S., Westphal, D. L., Baker, N., and Hyer, E. J.: A system for operational aerosol optical depth data assimilation over global oceans, J. Geophys. Res., 113, D10208, doi:10.1029/2007JD009065, 2007.

Zhang, R., Li, G., Fan, J., Wu, D. L., and Molina, M.: Intensification of Pacific storm track linked to Asian pollution, P. Natl. Acad. Sci. USA, 104, 5295-5299, doi:10.1073/pnas.0700618104, 2007. 